\title{
Antifouling activity of twelve demosponges from Brazil
}

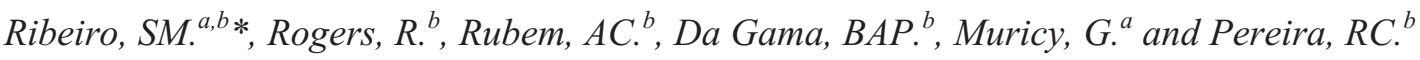 \\ ${ }^{a}$ Museu Nacional, Universidade Federal do Rio de Janeiro, Quinta da Boa Vista s/n ${ }^{o}$, São Cristóvão, \\ CEP 20.940-040, Rio de Janeiro, RJ, Brazil \\ ${ }^{b}$ Departamento de Biologia Marinha, Universidade Federal Fluminense, CP 100.644, CEP 24.001-970, Niterói, RJ, Brazil \\ *e-mail:suzimr@yahoo.com.br \\ Received April 23, 2012 - Accepted September 17, 2012 - Distributed August 31, 2013
}

(With 2 figures)

\begin{abstract}
Benthic marine organisms are constantly exposed to fouling, which is harmful to most host species. Thus, the production of secondary metabolites containing antifouling properties is an important ecological advantage for sessile organisms and may also provide leading compounds for the development of antifouling paints. High antifouling potential of sponges has been demonstrated in the Indian and Pacific oceans and in the Caribbean and Mediterranean seas. Brazilian sponges remain understudied concerning antifouling activities. Only two scientific articles reported this activity in sponges of Brazil. The objective of this study was to test crude extracts of twelve species of sponges from Brazil against the attachment of the mussel Perna perna through laboratorial assays, and highlight promising species for future studies. The species Petromica citrina, Amphimedon viridis, Desmapsamma anchorata, Chondrosia sp., Polymastia janeirensis, Tedania ignis, Aplysina fulva, Mycale angulosa, Hymeniacidon heliophila, Dysidea etheria, Tethya rubra, and Tethya maza were frozen and freeze-dried before extraction with acetone or dichloromethane. The crude extract of four species significantly inhibited the attachment of byssus: Tethya rubra $(\mathrm{p}=0.0009)$, Tethya maza $(\mathrm{p}=0.0039)$, Petromica citrina $(\mathrm{p}=0.0277)$, and Hymeniacidon heliophila $(\mathrm{p}=0.00003)$. These species, specially, should be the target of future studies to detail the substances involved in the ability antifouling well as to define its amplitude of action.
\end{abstract}

Keywords: Porifera, Demospongiae, antifouling, Perna perna, Brazil.

\section{Atividade anti-incrustante de doze demosponjas do Brasil}

\section{Resumo}

Organismos bentônicos marinhos estão expostos constantemente à incrustação, que pode ser danosa para a maioria das espécies. Assim, a produção de metabólitos secundários com propriedades anti-incrustantes é uma vantagem ecológica importante para organismos sésseis e pode também orientar o estudo de substâncias para o desenvolvimento de tintas anti-incrustantes. O alto potencial anti-incrustante de esponjas tem sido demonstrado nos oceanos Índico e Pacífico, nos mares Mediterrâneo e Caribenho. Esponjas brasileiras permanecem pouco estudadas em relação à atividade anti-incrustante. Apenas dois artigos científicos registraram essa atividade em esponjas do Brasil. O objetivo desse estudo foi testar os extratos brutos de doze espécies de esponjas do Brasil contra a fixação do molusco Perna perna através de ensaios laboratoriais e também destacar espécies promissoras para estudos futuros. As espécies Petromica citrina, Amphimedon viridis, Desmapsamma anchorata, Chondrosia sp., Polymastia janeirensis, Tedania ignis, Aplysina fulva, Mycale angulosa, Hymeniacidon heliophila, Dysidea etheria, Tethya rubra e Tethya maza foram congeladas e liofilizadas logo após a coleta e posteriormente procedeu-se a extração com acetona ou diclorometano. $\mathrm{O}$ extrato bruto de quatro espécies inibiu significativamente a fixação de bissos: Tethya rubra $(\mathrm{p}=0.0009)$, Tethya maza $(\mathrm{p}=0.0039)$, Petromica citrina $(\mathrm{p}=0.0277)$, e Hymeniacidon heliophila $(\mathrm{p}=0.00003)$. Essas espécies, especialmente, devem ser priorizadas em estudos futuros para detalhamento das substâncias envolvidas na capacidade anti-incrustante, bem como para definir sua amplitude de ação.

Palavras-chave: Porifera, Demospongiae, anti-incrustação, Perna perna, Brazil.

\section{Introduction}

Benthic marine organisms are constantly affected by the settlement of larvae, propagules and microorganisms on their surface (Railkin, 2003; Harder, 2009). Sponges often live in habitats with high level of spatial competition, such as coral reefs, but most sponge species have their surface free of fouling organisms (Rutzler, 1978; Diaz and Rutzler, 2001; Cedro et al., 2007). The presence of biofouling over the surface of a benthic organism may 
increase competition by space or food supply and may also affect growth and reproduction (Jackson and Buss, 1975; Orth and van Montfrans, 1984). Secondary metabolites may prevent or reduce this type of interaction, representing an important ecological advantage for benthic marine organisms (da Gama et al., 2008).

Besides the question of the ecological role of antifouling molecules of marine organisms, they are a promising tool for the development of commercial antifouling paints (Hellio et al., 2009). Biofouling on artificial structures causes financial losses of over $\$ 6.5$ billion dolars per year due to reduction in navigation efficiency of commercial ships caused by the increased friction by the irregular shape of the fouling organism (Holmes, 1970; Houghton, 1978; da Gama et al., 2003; Bhadury and Wright, 2004). Other important effect of biofouling on ship hulls is the dispersion of invasive species that may cause serious damage to native communities (Gollasch, 2002). The problem of marine fouling for navigation is so old that ancient civilizations such as the phoenicians (700 B.C.) used waxes, tar, asphalt and pitch on ship wood to avoid these organisms (Callow, 1990; Almeida et al., 2007). The first antifouling paints arose in the mid $19^{\text {th }}$ century using a strong toxic substance dispersed in a polymeric binder (Almeida et al., 2007). Around 1950, the development of organometallic paints (with tin, arsenic, mercury and others) preceded tributyltin-based antifouling paints, which became famous due to their efficiency and to their toxic effects on marine organisms and environment (Ruiz et al., 1995; Evans et al., 2000; Fernandez et al., 2005). Thus, several countries control the use of industrial antifouling products and the use of TBT was banned by the International Maritime Organization since January 2008 (IMO, 2002). Some alternative antifouling paints have been used to substitute organotin-based paints, but they may also alter the aquatic environment (Armstrong et al., 2000; Karlsson and Eklund, 2004; Löschau and Krätke, 2005). Antifouling molecules derived from marine organisms are promising leads for new commercial paints because these metabolites already exist in the sea and are biodegradable (Rittschof, 2001; Bhadury and Wright, 2004).

Several studies showed the antifouling potential of sponge secondary metabolites in the Indian and Pacific oceans, Caribbean and Mediterranean seas (Sera et al., 1999a; Kubanek et al., 2002; Hellio et al., 2005; Limna Mol et al., 2009). The antifouling property of marine benthic invertebrates from the Brazilian coast are still poorly known; to this date, only a single species of gorgonian, Phyllogorgia dilatata (Esper) and three of sponges were investigated: Geodia corticostylifera Hajdu et al., Mycale microsigmatosa Arndt and Aplysina fulva (Pallas). The extract of G. corticostylifera had strong antifouling activity, preventing the establishment of the bivalve Perna perna in laboratorial tests (Clavico et al., 2006), while extracts of $M$. microsigmatosa and $P$. dilatata selectively inhibited the establishment of barnacles and A. fulva did not showed antifouling effects in field experiments (Pereira et al., 2002). As there are more than 300 species of marine sponges in the Brazilian coast, this area of knowledge is clearly little explored in Brazil and there is great potential for the discovery of new antifouling compounds. The aim of this study is perform a screening for antifouling activity of twelve abundant sponge species from NE and SE Brazil, and point out promising species for further and more detailed investigations.

\section{Materials and Methods}

\subsection{Collection, maintenance of organisms and extraction}

Twelve species of sponges belonging to five orders were collected through free or SCUBA diving from tide zone to $20 \mathrm{~m}$ depth (Rio de Janeiro and Bahia States) from 2006 to 2008 (Table 1).

Juveniles of Perna perna, a common mussel in the Brazilian coast, were collected in December 2008 from the rocky coastal area at Itaipu beach (Niterói City, Rio de Janeiro State, Brazil, 2300'34" S-44²6'10" W). They were kept in a $230 \mathrm{~L}$ recirculating aquarium at constant temperature $\left(20^{\circ} \mathrm{C}\right)$, salinity $(35)$ and aeration to be further used in the assays.

After collection, sponge species were refrigerated through ice packages until arrive to laboratory and be frozen. Lyophilized sponges were extracted with acetone, except to Petromica citrina, which was extracted with dichloromethane. Sponges were extracted two times, first during 24 hours before be filtrated, and then extracted for 72 hours. The resulting extract from each filtration were added to previous filtered extract, to obtain the final extract.

\subsection{Antifouling assays}

Juveniles of Perna perna were carefully cleaned and separated from each other. The selection was done by considering active exposition of foot and crawling, showing that the mussels exhibit an exploratory behavior of the substrate.

The method described in da Gama et al. (2003) was followed to measure the antifouling activity against Perna perna. Water-resistant filter papers (control) were cut in circles of $9 \mathrm{~cm}$ in diameter and soaked with dichloromethane. A second set of $9 \mathrm{~cm}$ filter papers (treatment) were cut in a chessboard pattern $\left(1.5 \mathrm{~cm}^{2}\right.$ squares $)$. Treatment filters were soaked in sponge extracts diluted in dichloromethane, receiving the same ammount of extract or, in case of the control, soaked only with solvent and allowed to air dry. Control and treatment filters were placed in sterile polystyrene Petri dishes $(9 \mathrm{~cm}$ diameter $\mathrm{x}$ $1 \mathrm{~cm}$ height, Figure 1). Natural concentration of crude extracts were calculated and used for each sponge species (see Table 1).

Treatment filter paper was placed in the upper face (squared) and control in the lower face (entire) to offer the same area of treatment and control for byssus fixation. The dishes were completely filled with filtered natural sea water and three mussels ranging from 1.5 to 
Table 1 - Species studied and their localities of collection. RJ, Rio de Janeiro and BA, Bahia. *Calculated on the dry weight of sponge.

\begin{tabular}{|c|c|c|c|}
\hline Species/Author & Family/order & Locality/state & $\begin{array}{l}\text { Natural concentration* } \\
\text { of crude extract }(\%)\end{array}$ \\
\hline $\begin{array}{l}\text { Amphimedon viridis Duchassaing \& } \\
\text { Michelotti, } 1864\end{array}$ & Niphatidae/Haplosclerida & Angra dos Reis, RJ & 1.57 \\
\hline Aplysina fulva (Pallas, 1766) & Aplysinidae/Verongida & Arraial do Cabo, RJ & 1.62 \\
\hline Chondrosia sp. & Chondrillidae/Hadromerida & Angra dos Reis, RJ & 2.13 \\
\hline $\begin{array}{l}\text { Desmapsamma anchorata } \\
\text { (Carter, 1882) }\end{array}$ & Myxilidae/Poecilosclerida & Angra dos Reis, RJ & 1.60 \\
\hline $\begin{array}{l}\text { Dysidea etheria }(\mathrm{de} \\
\text { Laubenfels, 1936) }\end{array}$ & Dysideidae/Dictyoceratida & Angra dos Reis, RJ & 2.00 \\
\hline $\begin{array}{l}\text { Hymeniacidon heliophila } \\
\text { (Parker, 1910) }\end{array}$ & Halichondriidae/Halichondrida & Niterói, RJ & 2.05 \\
\hline $\begin{array}{l}\text { Mycale angulosa (Duchassaing \& } \\
\text { Michelotti, 1864) }\end{array}$ & Mycalidae/Poecilosclerida & Angra dos Reis, RJ & 1.95 \\
\hline Petromica citrina Muricy et al., 2001 & Halichondriidae/Halichondrida & Rio de Janeiro, RJ & 2.06 \\
\hline $\begin{array}{l}\text { Polymastia janeirensis } \\
\text { (Boury-Esnault, 1973) }\end{array}$ & Polymastiidae/Hadromerida & Arraial do Cabo, RJ & 1.59 \\
\hline $\begin{array}{l}\text { Tedania ignis (Duchassaing \& } \\
\text { Michelotti, 1864) }\end{array}$ & Tedaniidae/Poecilosclerida & Angra dos Reis, RJ & 1.83 \\
\hline Tethya maza Selenka, 1879 & Tethyidae/Hadromerida & Paraty, RJ & 2.68 \\
\hline $\begin{array}{l}\text { Tethya rubra Ribeiro \& } \\
\text { Muricy, } 2004\end{array}$ & Tethyidae/Hadromerida & Salvador, BA & 2.29 \\
\hline
\end{tabular}

$2.5 \mathrm{~cm}$ length were added (Figure 1). We also used an independent blank control in which both filter papers were embedded only with dichloromethane. For each assay, ten replicates were performed.

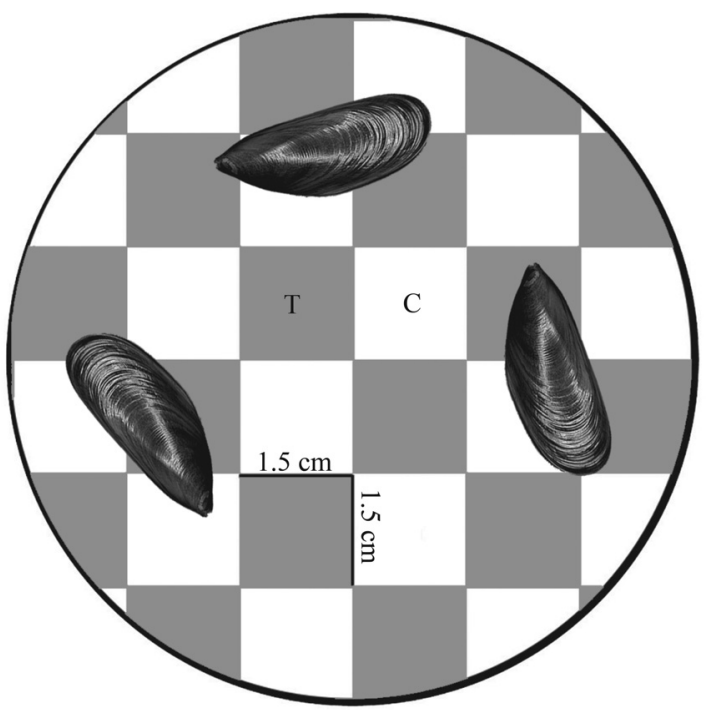

Figure 1 - Schematic draw of experimental unit containing treatment ( $\mathrm{T}$, gray squares) and control $(\mathrm{C}$, white squares) filter papers and three juveniles of Perna perna used in assays.
After 24 hours of experiment, all the records of attachment were quantified. Mussels were placed in plastic mesh bags tagged according to treatment and suspended in an aquarium, and checked for possible mortality due to exposure to the compounds tested, after 24 hours.

\subsection{Statistical analysis}

One-way analyses of variance (ANOVA) was used to compare the number of byssal thread attached among treatments and Dunnetts post hoc test was employed to detect the differences between treatments and independent controls. $T$ test were used to detected differences in

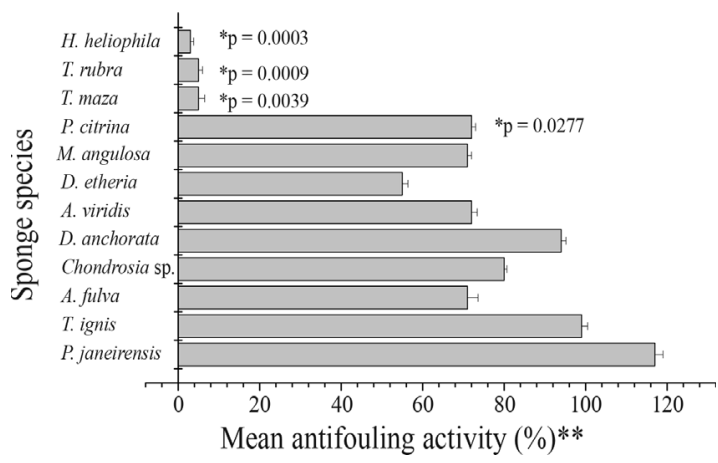

Figure 2 - Mean antifouling activity of sponge crude extracts. $* *$ Value in percentage of control with standard error indicated by bar. 
attachment between dependent control and treatment only for Petromica citrina assays (see Discussion). As assumptions of normality and homogeneity of variances were not met even after data transformations, KruskalWallis non-parametric tests were run (Zar, 1999). Differences were considered significant when $\mathrm{p}<0.05$ $(\alpha=5 \%)$.

\section{Results and Discussion}

From twelve sponge crude extracts, eleven were able to reduce mussel attachment, although only four in a statistically significant manner: Tethya rubra, T. maza, $H$. heliophila and P. citrina $(\mathrm{p}=0.0009,0.0039,0.00003$ and 0.0277 , respectively - Figure 2).

In all cases, the crude extract were nontoxic, since $24 \mathrm{~h}$ after test no mollusc was found dead.

Several metabolites from marine sponges were recorded by possessing antifouling properties against macro and/or microorganisms (Willemsen, 1994; Hellio et al., 2009), which reinforce the high potential of sponges to produce bioactive compounds.

Since most crude extracts tested in the present study were obtained with acetone (an organic solvent with polar affinities), we consider the dissolution of metabolites, from treatment filter paper, through the stagnant sea water in the Petri dish. These metabolites may act directly on the mussel inhibiting or stimulating byssus emission. All extracts tested were able to reduce mussel fixation, except for $P$. janeirensis.

Hymeniacidon heliophila was tested previously for antifouling activity, through in situ experiments, while Tethya spp. and P. citrina were tested here for the first time. The extract of $H$. heliophila was highly antifoulant in the present study (in which only 23 byssus were fixed, in total, against 132 in the blank controls), but did not deter fouling in North Carolina, U.S.A., in experiments in situ (Henrikson and Pawlik, 1998). The effectiveness of H. heliophila crude extract from Rio de Janeiro should represent an important ecological advantage, since this sponge occurs in the same zone of $P$. perna and is usually found living over them. Moreover, antipredation activity against fishes, sea urchins and hermit crabs had been demonstrated in extracts from $H$. heliophila (Ribeiro et al., 2010). On the other hand, field and laboratory experiments differ in several aspects, making hard direct comparisons. We must consider that in laboratory assays still water was used in contrast larvae to constant natural flow, and a single fouling organism in contrast with the large array of larve available in water column (da Gama et al., 2003). Although laboratory tests are very useful and reliable, the ecological significance is questionable and requires field testing to better interpretation of results (da Gama et al., 2003; Bakus et al., 1985). Different results found in the present study and Henrikson and Pawlik (1998) could be due to chemical differences between Rio de Janeiro and North Carolina specimens, or due to limitation concerning the method applied. It is an interesting point to be hereafter investigated.
From the four active species, three have sterols as majority components (pers. obs. in T. rubra, T. maza and H. heliophila). Despite being common and abundant in sponges, sterols were found to be effective inhibiting mussel and barnacle settlement and/or had lethal effect to larvae ascidian (Tsukamoto et al., 1997; Tomono et al., 1998; Sera et al., 1999a, b; Qiu et al., 2008). In addition to the sterols, other compounds as terpenoids, alkaloids, saponins, and fatty-acids, were indicated as active against barnacle larvae or molusc settlement (Goto et al., 1992; Fusetani, 2004; Roper et al., 2009). It is necessary investigate sterols, as well as minority components of $T$. maza, T. rubra, P. citrina and $H$. heliophila to identify the substance acting in $P$. perna attachment.

Although, the crude extract of A.viridis, $P$. janeirensis and T. ignis did not show activity against the settlement of mussels, the high antimicrobial property recorded from these species might be functional by inhibiting the attachment of marine microbiota in the early stages of fouling process (Kelman et al., 2001; Muricy et al., 1993). Experiments in natural conditions are good indicators by permitting several larvae in contact with extracts. Despite various experiments with larvae and macroinvertebrates that reveal the inhibitory capacity of sponges against the settlement, an in situ experiment found that just one out of 26 sponge species inhibited larval recruitment, suggesting that competent larvae use chemical characteristics of the sponges as cues for appropriate settlement sites (Bingham and Young, 1991).

We recommend the sponges T. maza, T. rubra, $H$. heliophila and $P$. citrina for future studies. Otherwise, the model organism used (bacteria, invertebrate larvae, or mussel) may have different levels of sensitivity by the chemical components. Thus, antifouling activity can be also detected using other organisms, and additional tests would be necessary to verify how effective these extracts are concerning antifouling process.

The existence of antifouling activity in these sponges seems to reflect the evolutionary history of each species, once it is not related to a pattern of taxonomic affinity or geographical distribution.

\section{Acknowledgments}

We are grateful to FAPERJ (S.M. Ribeiro postdoctoral fellowship), CAPES and FUJB for grants and $\mathrm{CNPq}$ for research productivity fellowships for BAPG, RCP and GM. We also thank C. Santos to collect T. rubra in Bahia State.

\section{References}

ALMEIDA, E., DIAMANTINO, TC. and DE SOUSA, O., 2007. Marine paints: The particular case of antifouling paints. Progress in Organic Coatings, vol. 59, p. 2-20.

ARMSTRONG, E., BOYD, KG. and BURGESS, JG., 2000 Prevention of marine biofouling using natural compounds from marine organisms. Biotechnology Annual Review, vol. 6, p. 221-241.

BAKUS, GJ., SCHULTE, B., JHU, S., WRIGHT, M., GREEN, M. and GOMEZ, P., 1985. Antibiosis and antifouling in 
marine sponges: laboratory vs. field studies. In: RUTZLER, K. (ed.) New Perspectives in Sponge Biology. Proceedings of the $3^{\text {rd }}$ International Sponge Conference, 1985. Washington, DC. p. 102-108.

BHADURY, P. and WRIGHT, PC., 2004. Exploitation of marine algae: biogenic compounds for potential antifouling applications. Planta, vol. 219, p. 561-578.

BINGHAM, BL. and YOUNG, CM., 1991. Influence of sponges on invertebrate recruitment: a field test of allelopathy. Marine Biology, vol. 109, p. 19-26.

BOURY-ESNAULT, N., 1973. Résultats Scientifiques des Campagnes de la 'Calypso'. Campagne de la 'Calypso' au large des côtes atlantiques de l'Amérique du Sud (19611962). I. 29. Spongiaires. Annales de l'Institut océanographique, vol. 49 , p. 263-295.

CALLOW, ME., 1990. Ship fouling: problems and solutions. Chemistry and Industry, vol. 5, p. 123-127.

CARTER, HJ., 1882. Some Sponges from the West Indies and Acapulco in the Liverpool Free Museum described, with general and classificatory remarks. Annals and Magazine of Natural History Series 5, vol. 9, p. 266-301.

CEDRO, VR., HAJDU, E., SOVIERZOSKY, HH. and CORREIA, MD., 2007. Demospongiae (Porifera) of the shallow coral reefs of Maceió, Alagoas State, Brazil. In CUSTÓDIO, MR., LÔBO-HAJDU, G., HADJU, E. and MURICY, G., (eds). Porifera research: biodiversity, innovation and sustainability. Rio de Janeiro: Museu Nacional. p. 233-237. Série Livros 28.

CLAVICO, EEG., MURICY, G., DA GAMA, BAP., BATISTA, D., VENTURA, CRR. and PEREIRA, RC., 2006. Ecological roles of natural products from the marine sponge Geodia corticostylifera. Marine Biology, vol. 148, p. 479-488.

DA GAMA, BAP., CARVALHO, AGV., WEIDNER, K., SOARES, AR., COUTINHO, R., FLEURY, BG., TEIXEIRA, VL. and PEREIRA, RC., 2008. Antifouling activity of natural products from Brazilian seaweeds. Botanica Marina, vol. 51, p. 191-201.

DA GAMA, BAP., PEREIRA, RC., SOARES, AR., TEIXEIRA, VL. and YONESHIGUE-VALENTIN, Y., 2003. Is the mussel test a good indicator of antifouling activity? A comparison between laboratory and field assays. Biofouling, vol. 19, p. 161-169.

DE LAUBENFELS, MW., 1936. A discussion of the sponge fauna of the Dry Tortugas in particular and the West Indies in general, with material for a revision of the families and orders of the Porifera. Washington: Carnegie Institution of Washington. $255 \mathrm{p}$.

DIAZ, AR. and RUTZLER, K., 2001. Sponges: an essential component of Caribbean coral reefs. Bulletin of Marine Science, vol. 69, p. 535-546.

DUCHASSAING, DE FP. and MICHELOTTI, G., 1864. Spongiaires de la mer Caraïbe. Harlem, Les heritiers Loosjes. $124 \mathrm{p}$.

EVANS, SM., BIRCHENOUGH, AC. and BRANCHATO, MS., 2000. The TBT ban: out of the frying pan into the fire? Marine Pollution Bulletin, vol. 40, p. 204-211.

FERNANDEZ, MAS., WAGENER, ALR., LIMAVERDE, AM., SCOFIELD, AL., PINHEIRO, FM. and RODRIGUES, EF., 2005. Imposex and surface sediment speciation: A combined approach to evaluate organotin in Guanabara Bay, Rio de Janeiro, Brazil. Marine Environmental Research, vol. 59, p. 435-452.

FUSETANI, N., 2004. Biofouling and antifouling. Natural Products Report, vol. 21, p. 94-104.
GOLLASCH, S., 2002. The importance of ship hull fouling as a vector of species introductions into the North Sea. Biofouling, vol. 18, p. 105-121.

GOTO, R., KADO, R., MURAMOTO, K. and KAMIYA, H., 1992. Fatty acids as antifoulants in a marine sponge. Biofouling, vol. 6, p. 61-68.

HARDER, T., 2009. Marine epibiosis: concepts, ecological consequences and host defence. Springer Series on Biofilms, vol. 4, p. 219-231.

HELLIO, C., TSOUKATOU, M., MARÉCHAL, J-P., ALDRED, N., BEAUPOIL, C., CLARE, AS., VAGIAS, C. and ROUSSIS, V., 2005. Inhibitory effects of Mediterranean sponge extracts and metabolites on larval settlement of the barnacle Balanus amphitrite. Marine Biotechnology, vol. 7, p. 297-305.

HELLIO, C., MARECHAL, JP., DA GAMA, BAP., PEREIRA, RC. and CLARE, AS., 2009. Marine natural products with antifouling activities. In HELLIO, C. and Yebra, DM. (Eds.). Advances in Antifouling Coatings and Technologies, p. 572-622.

HENRIKSON, AA. and PAWLIK, JR., 1998. Seasonal variation in biofouling of gels containing extracts of marine organisms. Biofouling, vol. 12, p. 245-255.

HOLMES, N., 1970. Marine fouling in power stations. Marine Pollution Bulletin, vol. 1, p. 105-106.

HOUGHTON, DR., 1978. Marine fouling and offshore structures. Ocean Management, vol. 4, p. 347-352.

IMO, International Maritime Organization, 2002. Antifouling systems, London, $31 \mathrm{p}$.

JACKSON, JBC. and BUSS, L., 1975. Allelopathy and spatial competition among coral reef invertebrates. Proceedings of the National Academy of Sciences of the United States of America, vol. 72, p. 5160-5163.

KARLSSON, J. and EKLUND, B., 2004. New biocide-free anti-fouling paints are toxic. Marine Pollution Bulletin, vol. 49 , p. 456-464.

KELMAN, D., KASHMAN Y., ROSENBERG E., ILAN M., IFRACH I., LOYA Y., 2001. Antimicrobial activity of the reef sponge Amphimedon viridis from the Red Sea: evidence for selective toxicity. Aquatic Microbial Ecology, vol. 24, p. 9-16.

KUBANEK, J., WHALEN, KE., ENGEL, S., KELLY, SR., HENKEL, TP., FENICAL, W. and PAWLIK, JR., 2002. Multiple defensive roles for triterpene glycosides from two Caribbean sponges. Oecologia, vol. 131, p. 125-136.

LIMNA MOL, VP., RAVEENDRAN, TV. and PARAMESWARAN, PS., 2009. Antifouling activity exhibited by secondary metabolites of the marine sponge Haliclona exigua (Kirkpatrick). International Biodeterioration \& Biodegradation, vol. 63, p. 67-72.

LÖSCHAU, M. and KRÄTKE, R., 2005. Efficacy and toxicity of selfpolishing biocide-free antifouling paints. Environmental Pollution, vol. 138, p. 260-267.

MURICY, G., HAJDU, E., ARAUJO, FV. and HAGLER, AN., 1993. Antimicrobial activity of Southwestern Atlantic shallow-water marine sponges (Porifera). Scientia marina, vol. 57, p. 427-432.

MURICY, G., HAJDU E., MINERVINO, JV., MADEIRA, AV. and PEIXINHO, S., 2001. Systematic revision of the genus Petromica Topsent (Demospongiae: Halichondrida), with a new species from the southwestern Atlantic. Hydrobiologia, vol. 443, p. 1-3.

ORTH, RJ. and VAN MONTFRANS J., 1984. Epiphyte-seagrass relationships with an emphasis on the role of micrograzing: a review. Aquatic Botany, vol. 18, p. 43-69. 
PALLAS, PS., 1766. Elenchus Zoophytorum sistens generum adumbrations generaliores et specierum cognitarum succinctas descriptiones cum selectis auctorum synonymis. The Hague: Petrum van Cleef. $451 \mathrm{p}$.

PARKER, GH., 1910. The reactions of sponges, with a consideration of the origin of the nervous system. Journal of Experimental Zoology, vol. 8, p. 765-805.

PEREIRA, RC., CARVALHO, AGV., DA GAMA, BAP. and COUTINHO, R., 2002. Field experimental evaluation of secondary metabolites from marine invertebrates as antifoulants. Brazilian Journal of Biology, vol. 62, p. 311320.

QIU, Y., WEI, Z., XU, M., LI, Q. and HAN, W., 2008. New A-nor steroids and their antifouling activity from the Chinese marine sponge Acanthella cavernosa. Steroids, vol. 73, p. 1500-1504.

RAILKIN, AI., 2003. Marine biofouling: colonization processes and defenses. Boca Raton, Florida, USA: CRC Press.

RIBEIRO, SM. and MURICY, G., 2004. Four new sympatric species of Tethya (Demospongiae: Hadromerida) from Abrolhos Archipelago (Bahia State, Brazil). Zootaxa, vol. 557, p. 1-16.

RIBEIRO, SM., BIANCO, EM., ROGERS, R., TEIXEIRA, VL. and PEREIRA, RC., 2010. Chemical defense of Hymeniacidon heliophila (Porifera: Halichondrida) against tropical predators. Brazilian Journal of Oceanography, vol. 58, p. 315-321.

RITTSCHOF, D., 2001. Natural product antifoulants and coatings development. In McCLINTOCK, JB. and BAKER, BJ. (eds). Marine chemical ecology. Boca Raton, Flórida, USA: CRC Press. p. 543-566.

ROPER, KE., BEAMISH, H., GARSON, MJ., SKILLETER, GA. and DEGNAN, BM., 2009. Convergent antifouling activities of structurally distinct bioactive compounds synthesized within two sympatric Haliclona demosponges. Marine Biotechnology, vol. 11, p. 188-198.
RUIZ, JM., BRYAN, GW. and GIBBS, PE., 1995. Effects of tributyltin (TBT) exposure on the veliger larvae development of the bivalve Scrobicularia plana (da Costa). Journal of Experimental Marine Biology and Ecology, vol. 186, p. 53-63.

RUTZLER, K., 1978. Sponges in coral reefs. In STODDART, DR. and JOHANNES, RE. (eds). Coral Reefs: Research Methods. Paris: UNESCO. Monographs on Oceanographic Methodology no. 5.

SELENKA, E., 1879 [1980] Ueber einen Kieselschwamm von achtstrah ligem Bau, und über Entwicklung der Schwammknospen. Zeitschrift für Wissenschaftliche Zoologie, vol. 33, p. 467-476.

SERA, Y., ADACHI, K., NISHIDA, F. and SHIZURI, Y., 1999a. A new sesquiterpene as an antifouling substance from a Palauan marine sponge, Dysidea herbacea. Journal of Natural Products, vol. 62, p. 395-396.

SERA, Y., ADACHI, K. and SHIZURI, Y., 1999b. A new epidioxy sterol as an antifouling substance from a Palauan marine sponge, Lendenfeldia chondrodes. Journal of Natural Products, vol. 62, p. 152-154.

TOMONO, Y., HIROTA, H. and FUSETANI, N., 1998. Antifouling compounds against barnacle (Balanus amphitrite) larvae from the marine sponge Acanthella cavernosa. In WATANABE, Y and FUSETANI, N. (eds.). Sponge sciences - multidisciplinary perspectives. Tokyo: SpringerVerlag. p. 413-426.

TSUKAMOTO, S., KATO, H., HIROTA, H. and FUSETANI, N., 1997. Antifouling terpenes and steroids against barnacle larvae from marine sponges. Biofouling, vol. 11, p. 283-291.

WILLEMSEN, PR., 1994. The screening of sponge extracts for antifouling activity using a bioassay with laboratoryreared cyprid larvae of the barnacle Balanus amphitrite. International Biodeterioration \& Biodegradation, vol. 34, p. 361-373.

ZAR, JH., 1999. Biostatistical analyses. New Jersey, USA: Prentice-Hall. 